\title{
Second record of Derolathrus abyssus Yamamoto et Parker, 2017 (Coleoptera: Jacobsoniidae) from Upper Cretaceous Burmese amber
}

\author{
Вторая находка Derolatbrus abyssus Yamamoto et Parker, 2017 \\ (Coleoptera: Jacobsoniidae) в верхнемеловом бирманском янтаре
}

\author{
J. Háva*, A. Allen** \\ И. Гава*, А. Алменн* \\ * Forestry and Game Management Research Institute, Strnady 136, Praha 5 - Zbraslav CZ-156 00 Czech Republic. E-mail: \\ jh.dermestidae@volny.cz. ORCID ID: 0000-0001-8076-9538. \\ * Научно-исследовательский институт охотничьего хозяйства, Стрнады 136, Praha 5 - Збраслав CZ-156 00 Чешская Рес- \\ публика. \\ ** 2305 S. Delphinium Ave, Star, Idaho 83669 U.S.A. \\ **2305 С. Дельфиниум авеню, Стар, Айдахо 83669 США.
}

Key words: faunistics, Coleoptera, Jacobsoniidae, Derolathrus, Upper Cretaceous, Burmese amber.

Ключевые слова: фаунистика, Coleoptera, Jacobsoniidae, Derolathrus, верхний мел, бирманский янтарь.

\begin{abstract}
The second specimen of species Derolathrus abyssus Yamamoto et Parker, 2017 from the Upper Cretaceous Burmese amber is recorded.

Резюме. В статье приводится информация о находке второго экземпляра Derolathrus abyssus Yamamoto et Parker, 2017 в верхнемеловом бирманском янтаре.

\section{Introduction}

The genus Derolathrus Sharp in Sharp et Scott, 1908 recently contains 10 species [Yamamoto et al., 2017]; only two species are fossils Derolathrus abyssus Yamamoto et Parker, 2017 (Burmese amber) and Derolathrus groehni Cai, Leschen, Liu et Huang, 2016 (Baltic amber).
\end{abstract}

\section{Material and Methods}

Specimen is deposited in Jiří Háva, Private Entomological Laboratory and Collection, Prague-west, Czech Republic.

The photo (Fig. 1) was taken by A. Allen.

\section{Results}

\section{Coleoptera: Jacobsoniidae}

Derolathrus abyssus Yamamoto et Parker, 2017 Fig. 1

Material. Myanmar: Kachin State, Hukawng Valley; Cretaceous, lowermost Cenomanian, 1 spec. (unsexed), J. Háva det. The complete beetle is included in a poorly transparent amber piece, with dimensions of $15 \times 12 \times 7 \mathrm{~mm}$. Syninclusions consist of numerous minute organic particles.

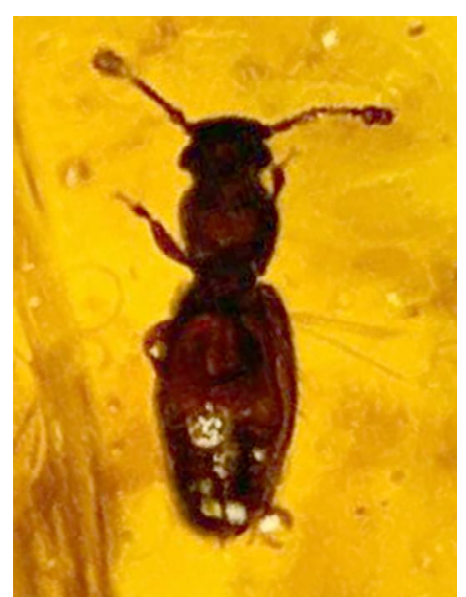

Fig. 1. Derolathrus abyssus, habitus, dorsal view.

Рис. 1. Derolatbrus abyssus, внешний вид, Аорсально.

Remarks. This species has been described based on single holotype specimen [Yamamoto et al., 2017]. This is the second known specimen for the species. Body length 0.8 $\mathrm{mm}$. Visible only ventraly. It must therefore be added for description that the species has the length $0.73-0.80 \mathrm{~mm}$.

\section{Acknowledgements}

The paper was supported by the Ministry of Agriculture of the Czech Republic, institutional support MZE-RO0118.

\section{References}

Yamamoto S., Takahashi Y., Parker J. 2017. Evolutionary stasis in enigmatic jacobsoniid beetle // Gondwana Research. Vol.45. P. 275-281. 